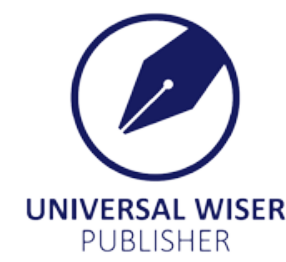

\title{
The Habit of Savings among College Students
}

\author{
David Doe Fiergbor
}

KBF Centre for International Studies, Ghana, P. O. Box GS 6040, Bortianor Sea View, Near Bojo Beach Resort, Accra, Ghana E-mail: daviddoef@gmail.com

\begin{abstract}
It is not easy to come by money however, money can easily 'leave' one's possession if not properly managed. Money management skills are therefore important skills for life especially in the youthful days as wealth creation is not entirely about how hardworking an individual is but factors such as his/her ability to understand how money works and apply its management principles are of essence. Savings play an integral aspect of an individual's financial management skills since it is the bedrock of personal financial success. Savings is not just about setting money aside for future use but also has to do with keeping anything of economic value. Savings are securing assurance today for tomorrow's uncertainties. This paper sought to examine the habit of savings among the college students. The result indicated that the majority of the college students do not save as a result of certain contributory factors such as meager salaries and economic hardships. Also, the majority of the college students do not have definite financial management plans such as savings as a result of inadequate financial literacy. The study concluded on the need for public education on key money management skills such as savings which is a recipe for wealth creation.
\end{abstract}

Keywords: habit, savings, financial literacy, financial management

\section{Introduction}

The habit of savings plays an important role in everyday financial decisions ${ }^{[9]}$. The study has revealed that there subsists a progressive correlation amid savings and growth. Constant act of saving is very important to the financial independence and stability Greater savings has established to be a vital element of fiscal progression. In an era of unstable financial economies, one has to ensure and implement prudent financial management practices to achieve personal financial independence of which savings are fundamentally key. Savings have therefore become indispensable in the life of college students who strive to achieve personal financial independence as the continent is largely plagued with ever-increasing huge rates of unemployment. Financial literacy in the area of saving is therefore paramount as the financial industry is ever-evolving with innovative products.

An individual's financial literacy level is his/her ability to make informed judgments and to take effective actions regarding the current and future use and management of money ${ }^{[4]}$. Financial literacy includes the ability to comprehend financial sets. For example, having current and savings accounts, having a bookkeeping system, planning for the future like saving or investing for long term goals like education, home, vacation, etc. Financial literacy also pleas for prudent expenditure. This means organizing resources, tracking costs, repaying bills on time, etc. Financial literacy affects financial decision making. Ignorance about basic financial concepts can be linked to a lack of retirement planning, lack of participation in the stock market, and poor borrowing deeds ${ }^{[10]}$. This means that financial illiteracy can travel a long way through the youthful stages to the retirement stage of an individual. It is a driving force in the life of an individual.

Even though habit formation is not an easy act, once the habit of savings is formed, it affects one's saving ability because habit formation improves a person's perception and intention towards saving ${ }^{[9]}$. Once a habit is formed, it affects an individual's consumption and savings ${ }^{[1]}$. Savings is a function of one's past savings and a combination of current income changes and "discounted value of future income changes". The habit of saving is therefore very vital as optimum financial leverage does not only encourage sound economic stable life but also pivotal in ensuring and assuring a better lifestyle in areas of healthy living, quality health care, education and better accessibility to basic social amenities. Savings is an integral part of life as it is needed in every facet of life and the ability to cultivate the habit would enhance financial success in life. This study sought to examine the habit of savings among college students and its impact on their basic financial planning skills that are needed for a successful life.

Copyright (C2020 David Doe Fiergbor

DOI: https://doi.org/10.37256/ges.11202069.38-43

This is an open-access article distributed under a CC BY license

(Creative Commons Attribution 4.0 International License)

https://creativecommons.org/licenses/by/4.0/ 


\section{Literature review}

The financial systems of the 21 st Century have been growing with speed, sophistication and becoming a more complex world ${ }^{[7]}$. The economic and social environment in which people take financial decisions has changed and this change is set to continue with the dynamic and ever-changing technology. Financial products and services have multiplied along with technology and other means of marketing them ${ }^{[5]}$. Therefore, to be financially successful, one needs to understand and apply basic financial management skills such as savings to personal finances.

$\mathrm{OECD}^{[12]}$, defined financial literacy as a combination of awareness, knowledge, skills, attitude, and behavior necessary to make sound financial decisions and ultimately achieve individual financial wellbeing. Ambre ${ }^{[3]}$, opined that financial literacy starts at home itself where children are educated about how to handle money such as to save and spend wisely. The key competencies of financial literacy are money basics, budgeting, savings and planning, borrowing and debt literacy, financial products, and recourse and self-help. Money fundamentally relates to the knowledge, skills, and understanding required for the most essential day to day calculations. Examples include numeracy and money management skills. Numeracy is the skill that permits people to evaluate the appropriateness of expenses for themselves. Numeracy is the foundation of considering which financial products are cost-effective. Also, numeracy has been found to play an important role in influencing saving and even budgeting. Huston ${ }^{[8]}$, proposed that financial literacy must also include the use of financial knowledge; the argument being that absent demonstrated ability to apply financial acquaintance, a person cannot be considered as being financially literate.

Saving is a basic components of financial literacy. It is therefore imperative that for an individual to understand the rudiments of personal savings, he or she must be financially literate to some extent. While several widely used definitions of financial literacy exist, all of them generally implies the ability of individuals to obtain, understand and evaluate information required to make decisions to secure their financial future as best as possible. Financial literacy is a person's knowledge of facts, concepts, principles, and technological tools that are fundamental to being smart about money. Savings entails accrual of assets. Accumulation of anything of lasting value is also savings. The part of income not spent is the part that is saved. Thus savings equivalents income minus consumption ${ }^{[6]}$. Sonuga-Barke \& Webley ${ }^{[14]}$, argue that saving is defined in terms of the value of a set of activities (going to the counter and depositing money), made concerning one or other establishments (bank or building society). From the practical point of view, savings is, therefore, an adaptive reaction to the income limitation problem.

Todaro \& Smith ${ }^{[15]}$, asserted that for any society to take-off into self-sustaining fiscal progression, they have to rally both local and transnational savings to help them make a significant investment to spawn economic growth. Alguacil et al ${ }^{[2]}$, also believed that rallying both local and transnational savings is obligatory to make a significant domestic investment. Their study established the exploration of Solow's model that, "higher savings precedes economic growth" (2004:281). Odhiambo ${ }^{[11]}$, noted in his study that as far as Kenya is concerned, savings have contributed enormously to the development of the fiscal sector stressing the fact that savings have played an important role in the economies of many unindustrialized countries. "The habit of savings plays an important role in everyday financial decisions" ${ }^{[9]}$. To them, a continuous act of saving is central to the financial freedom and stability of individuals. Even though habit development is not an easy action, once the habit of savings is molded, it affects one's saving ability. Habit formation improves a person's perception and intention towards savings. Allesie \& Lusardi ${ }^{[1]}$, also believed that once a habit is formed, it tends to affect an individual's consumption and savings. They noted that savings are a function of one's past savings and a recipe for current income changes and "discounted value of future income changes". In industrial society, savings are usually done by diverse people and for diverse reasons ${ }^{[13]}$.

\section{Methodology}

The random sampling technique was the method used for this study. Primary data was collected using a semistructured interview guide from 100 randomly selected college students who were mainly engaged in pupil teaching in the Ada East District of Ghana. The respondents were young adults and adults between the ages of 20 and 35years. Secondary data collected was based on published information, journals and reports found on the internet.

\section{Presentation of findings}

The findings of the study are presented in the figures below.

From figure 1, respondents were asked the range of their monthly salaries. The results indicated that 64 respondents representing the majority of $64 \%$ earned less than Gh $\$ 500.00$. Whiles $28 \%$ of the respondents also earned between 
Ghф501.00 and Ghф1000.00 with the remaining earning above Gh $\varnothing 1000.00$ and between Ghф2000.00. None of the respondents earned above Ghф2000.00.

Figure 2 shows that $31 \%$ of the respondents responded in affirmation that they had savings plan whilst the majority $69 \%$ responded otherwise.

Figure 3 showed that $25 \%$ of the respondents saved less than $6 \%$ of their salaries whereas $16.1 \%$ saved between 10 and $19 \%$. In total, only $31 \%$ of the college students who participated in the study responded to the question on the proportion of their salaries they set aside for savings. In effect, the remaining $69 \%$ do not save for reasons such as meagre salaries and unplanned savings plan among others.

Figure 4 showed that $100 \%$ of the respondents believed that their savings could sustain their expenses for a maximum duration of three months. None of the respondents' savings could sustain them beyond a period of three months.

From figure 5, none of the respondents saves with "susu" companies. However, $12.9 \%$ of the respondents each save with savings and loans and microfinance companies. The majority $58 \%$ save with banks, the remaining $16 \%$ did not save with any of these institutions. These respondents save with insurance companies and some other forms of financial institutions.

Figure 6 shows that the majority of respondents constituting $87 \%$ who were college students did not have definite investment plans. This is in contrast to the remaining $13 \%$ that had well outlined investment plans.

From figure 7 , the majority $65 \%$ of the respondents intended to plan their retirement with various life insurance policies whilst $8 \%$ intended to use mutual funds, the remaining $27 \%$ intended to use savings accounts

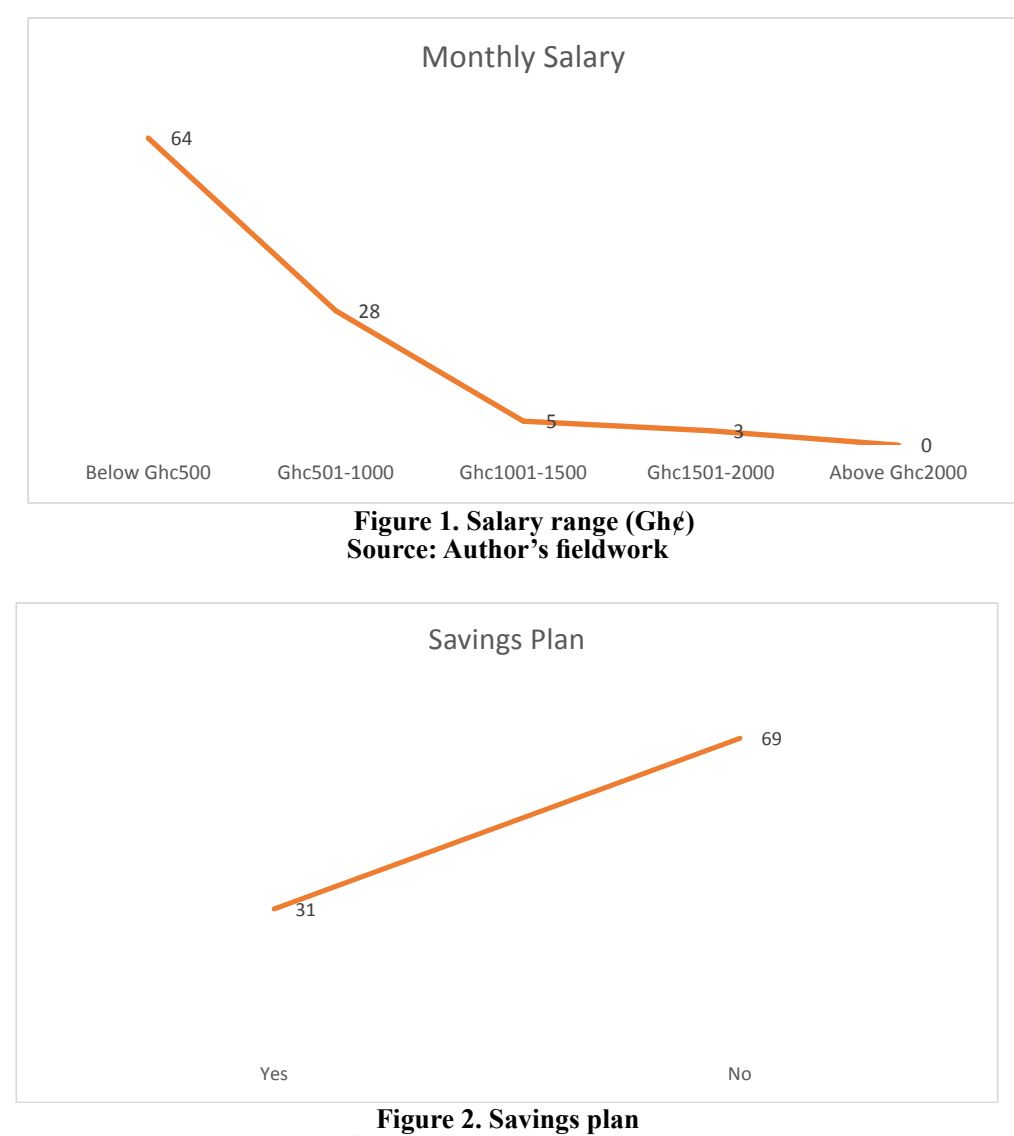

Source: Author's fieldwork 


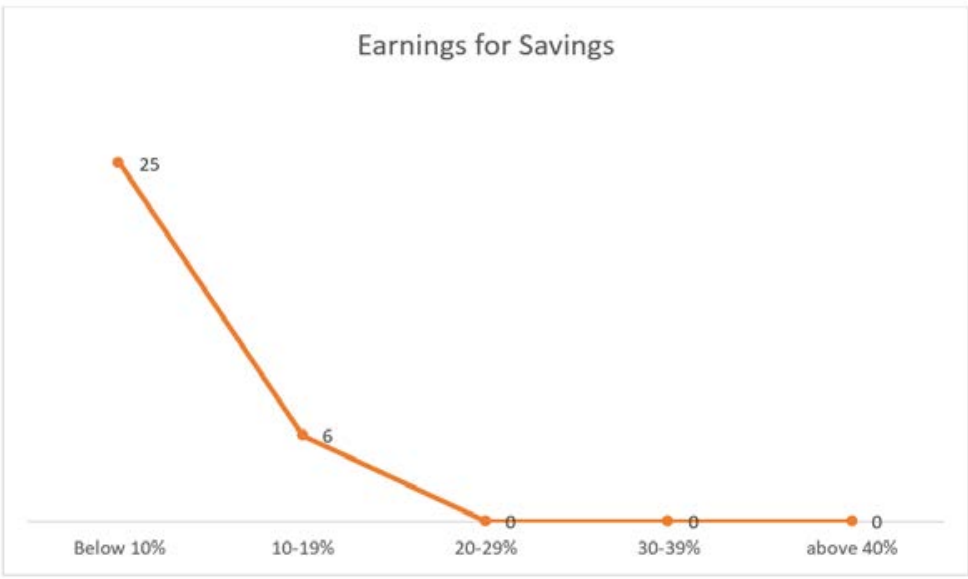

Figure 3. Proportion of earnings set aside for savings Source: Author's fieldwork

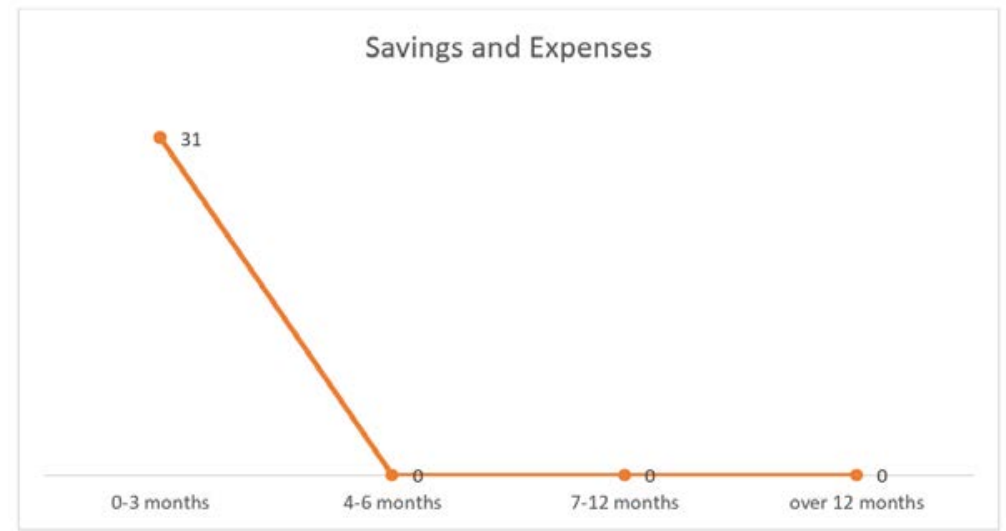

Figure 4. How long ones' savings can sustain recurrent expenses Source: Author's fieldwork

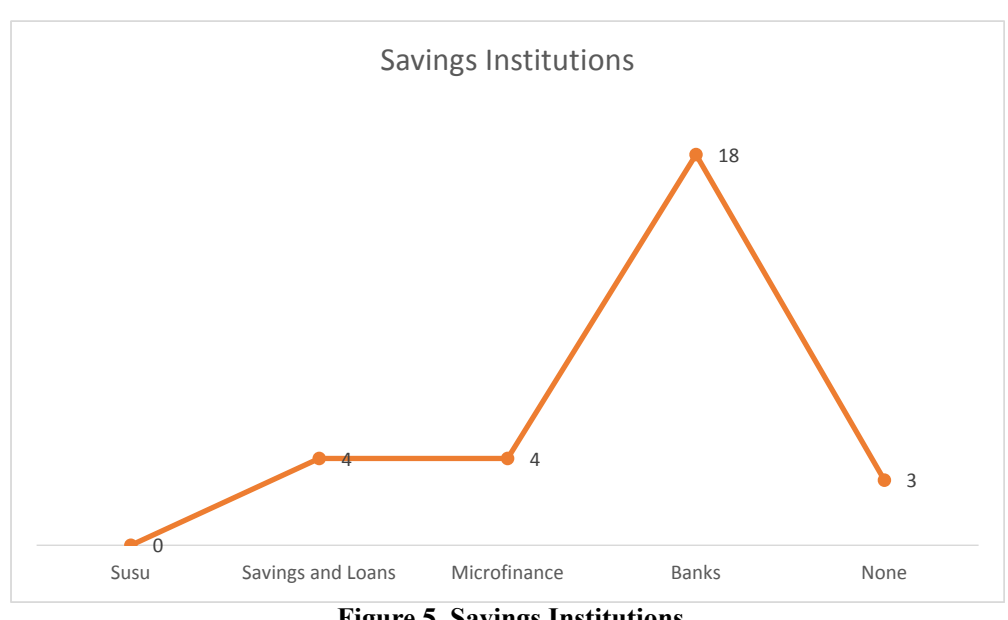

Source: Author's fieldwork 


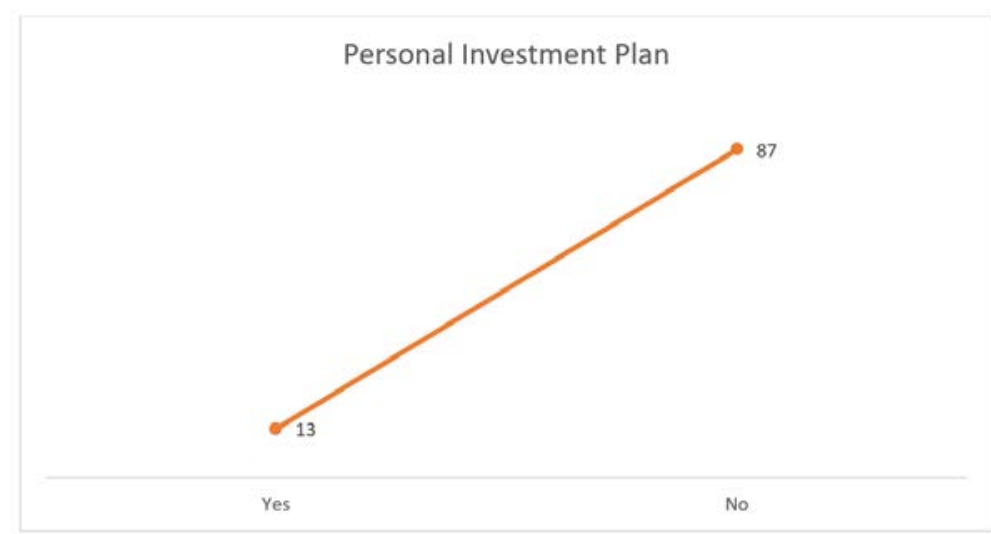

Figure 6. A well outlined personal investment plan Source: Author's fieldwork

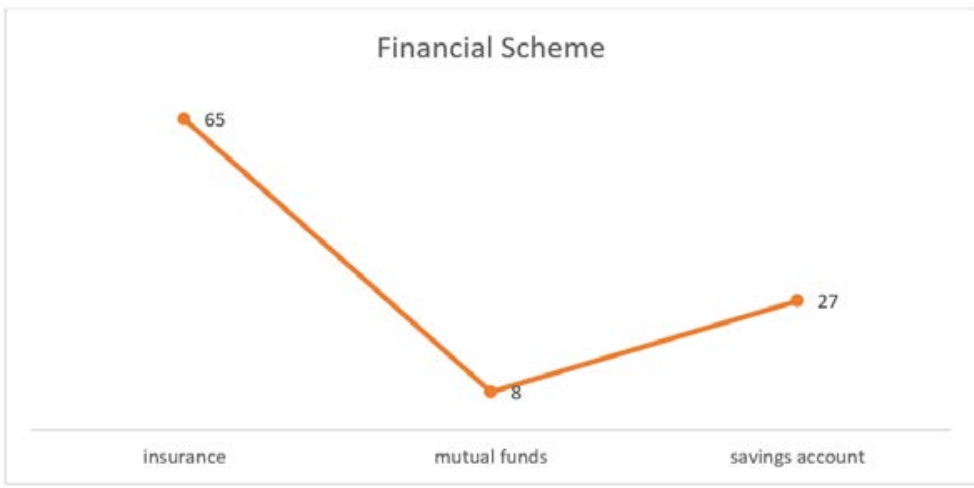

Figure 7. Preferred financial scheme for retirement plan Source: Author's fieldwork

\section{Results and Discussions}

From the study, it was observed that the majority of college students did not earn much income hence they faced challenges meeting their financial obligations and as a result, they were unable to save adequately for their future financial needs. The majority of college students did not have savings plans that could sustain their recurrent expenditures in case of unexpected loss of employment income. However, the few who save did so intermittently. This was evident in the fact that the majority save less than $10 \%$ of their income and even those who save could only be survived on their savings for three months.

Most respondents believed their incomes were not enough to set apart aside as savings. Whiles almost all young people believed that savings are a good habit, only a few were making plans to start saving for their old age. The majority of respondents believe they were young and have more years to work and accumulate wealth before retiring. Most college students operate savings accounts with banks and the majority would want to plan their retirement using insurance schemes.

\section{Summary and conclusion}

Savings play an integral part in a person's life as it is the wheel that drives financial independence and freedom. It was evident that the habit of savings among college students is not encouraging as the basic understandings for financial freedom and independence were not adequate. Savings in its simplest definition is setting something of value aside for future use; it is, therefore, important that college students understand the essence of savings despite their levels of income. It would be in the interest of college students to consider acquiring further studies to increase their income. The idea of exploring multiple sources of income would be of importance. The need for financial education is therefore important to enhance financial literacy among college students and to eradicate poverty in developing countries. 


\section{References}

[1] Alessie, R., Lusardi, A. \& Aldershof, T. Income and wealth over the life cycle: Evidence from panel data. Review of Income and Wealth. 1997; 43(1): 1-32.

[2] Alguacil, M., Cuadros, A. and Orts, V. Does saving matter for Growth? Mexico (1970-2000). Journal of International Development. 2004; 16: 281-290.

[3] Ambre, A. Personal finance-Five tips on giving allowance to kids. Economic Times. 2012.

[4] Basu, S. White Paper: Financial literacy and the life cycle. White House. Between Knowledge and Behavior. Choice? Joint Center for Housing Studies, Harvard University Conference on Aging. [Online] Available from http://216.87.66.5/ member/govt_relation Consumer Education. 2005; 10: 27-31.

[5] Greenspan, A. The Importance of Financial Education Today. Social Education. 2005; 69(2): 64-65.

[6] Henderson, J.V. and Poole, W. Principles of Economics. Lexington, Mass: D.C. Heath. 2005; 279-81.

[7] Hilgert, A. M. Hogarth, J. M. Household Financial Management: The Connection. 2002.

[8] Huston, S. Measuring Financial literacy. Journal of Consumer Affairs. Summer. 2010; 44(2): 296-316.

[9] Loibl, C., Kraybill, D. S. and DeMay, S. W. Accounting for the role of habit in regular saving. Journal of Economic Psychology. 2011; 32: 581-592.

[10] Lusardi, A. Financial Literacy: An Essential Tool for Informed Consumer. 2008.

[11] Odhiambo, M. N. Financial depth, savings and economic growth in Kenya: A dynamic causal linkage. Economic Modelling. 2008; 25: 704-713.

[12] OECD-INFE. Measuring financial literacy: Core questionnaire in measuring financial literacy: Questionnaire and guidance notes for conducting an internationally comparable survey of financialliteracy. Paris: OECD. OECD International Network on Financial Education (INFE). 2011. Downloaded from http://www.oecd.org/finance/ financialeducation/49319977.pdf on 10 May 2019.

[13] Samuelson, P. and Samuelson, W. Economics. McGraw-Hill International Book Company, Auckland. 1980.

[14] Sonuga-Barke, E., \& Webley, P. Children's saving: A study in the development of economic behavior. Hove: LEA. 1993.

[15] Todaro, P. M. and Smith, S. C. Economic Development (9th Ed.). Pearson Education Limited, Englan. 2006. 